\title{
sciendo
}

CIVIL AND ENVIRONMENTAL ENGINEERING REPORTS

E-ISSN 2450-8594

CEER 2018; 28 (2): 085-100

DOI: $10.2478 /$ ceer-2018-0021

Original Research Article

\section{CARTOGRAPHIC METHODS OF PRESENTATION THE AVERAGE TRANSACTION PRICES OF THE UNDEVELOPED LAND}

\author{
Marek OGRYZEK ${ }^{1}$, Mateusz CISKI \\ University of Warmia and Mazury in Olsztyn, Olsztyn, Poland
}

\begin{abstract}
The article presents a description of basic cartographic methods used to visualize spatial data. Information on average transaction prices of the undeveloped land in WarmińskoMazurskie voivodeship, from The Agricultural Property Agency, Regional Office in Olsztyn, was the basis for map creation. Unified data allows the accurate presentation of information and highlights the differences in selected cartographic methods. The objective of this article is to describe the selection process of the best method for presenting spatial data by identifying the data structure and visualization purpose; as well as to describe the different types of data presentation for its potential use for work related to activities performed by professionals dealing with the real estate market and by individuals.
\end{abstract}

Keywords: cartographic methods, spatial data, transaction prices of the undeveloped land

\section{INTRODUCTION}

The process of accurate choice of spatial data presentation method is a very important aspect of the work, sometimes overlooked in the analysis process.

\footnotetext{
${ }^{1}$ Corresponding authors: University of Warmia and Mazury in Olsztyn, Faculty of Geodesy Geospatial and Civil Engineering, Prawocheńskiego st 15, 10-720 Olsztyn, Poland, e-mail: marek.ogryzek@uwm.edu.pl, tel.+480895233977
} 
The end result of cartographic modelling and spatial data analysis is always a map -almost all users of geoinformation systems use this form of data presentation [4]. Ease of map creation (,side" effect of the development of science and technology), and at the same time inadequate cartographic editing can cause unreadability of the message. In the age of computerization of cartographic methods, the user is facing an important choice - not always the solution suggested by the computer program is the best solution. Unusuality of the problem or uniqueness of the analysis area may require additional time or different method or software [8]. Therefore, the process of selecting a data presentation method must be preceded by the thorough analysis of the data structure - relevant aspects needs to be emphasized in order to show appropriate facts, and relationship between data needs to be realized. Many spatial presentation methods in single research are often used, which further increases the importance of a right choice $[1,10]$.

Property value maps used to compare methods represent the market value of the property, which is defined as the most likely price possible to get on the market, based on transaction prices on the local market [7]. The following is a series of data presentation methods with examples - based on information of average transaction prices of the undeveloped land in Warmińsko-Mazurskie voivodeship in years 2014-2016, from The Agricultural Property Agency, Regional Office in Olsztyn. The data (starting from linear range method) is presented with division into 13 counties of Regional Office in Olsztyn.

\section{CARTOGRAPHIC METHODS}

Spatial diversification of given phenomenon can be visualized (and emphasized if necessary) with a suitable cartographic method. There are various ways available to present geospatial, social and economic issues on maps. Choice depends mainly from the characteristics of presented topic, and from the properties of the method itself $[1,10]$. Geographic objects and features can be presented by appropriate characters, located at the points of occurrence, where each point corresponds to a specified feature. Points usually symbolize small objects, not included within the map scale (e.g. trees or memorials). Linear signs represent only the length and extent of an object, when thickness and area are not important. Surface characterized features are presented by range lines and its filling, hachure and colour. Surface usually symbolize bigger objects, included fully within the map scale (e.g. lakes, swamps, forests). Capturing the feature in relation to surface (usually units of administrative division), it can be presented in a form of diagram map. Intensity of the given feature in relation to surface can be also visualized with a colour scale, by using choropleth map [5]. Two basic categories of cartographic methods used to visualize spatial data are qualitative 
and quantitative methods. Qualitative methods relate to non-measurable qualities, indicating only the presence of shown feature. Quantitative methods however, shows the intensity of a given phenomenon [4].

\section{QUALITATIVE METHODS}

With qualitative methods, the emphasis is placed on distinction of features, rather than its magnitude or hierarchy. These methods were used since the very beginning of cartography. Using the appropriate characters, these methods allows to distinguish individual elements or groups of elements. In these methods, indication and distinction of particular objects is important, not its quantitative characteristics. Qualitative methods includes: signature method, range method and surface method $[3,6]$.

\subsection{Signature methods}

The main idea of the signature method is to use symbols in the form of appropriately selected characters or geometric figures, in order to present data. Signatures can vary in shape, colour, or size; its density is usually marked on the map in compact form. Due to the shape, signatures are divided into geometric, symbolic, picture, letter and linear signatures. The most common are geometric signatures (Fig. 1), because of the simplicity of their structure and ease of understanding. Symbolic signatures usually means a simplified form of the presented object. Linear signatures are less frequent, more commonly found on maps showing socio-economic issues $[3,6]$. To distinguish the presented objects,

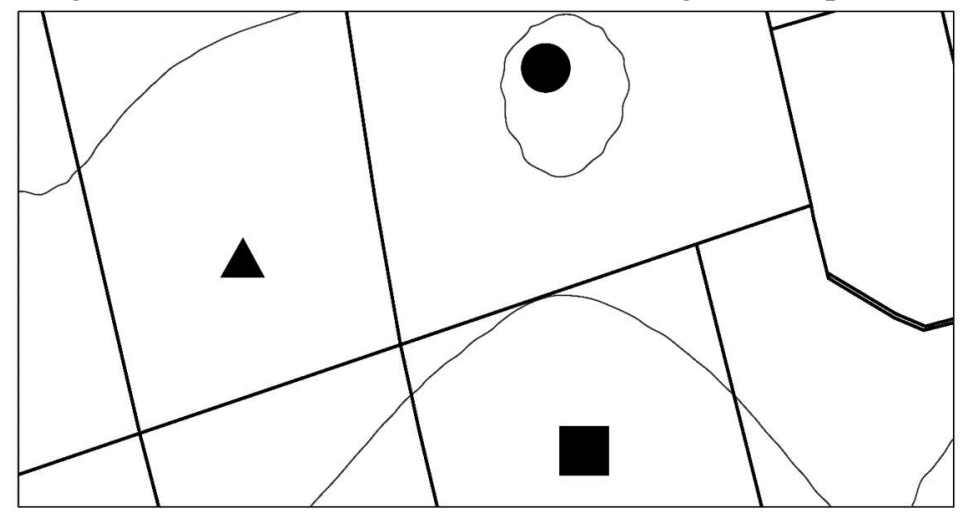

Fig. 1. Simple geometric signatures

signatures of different colours and shapes are used. Using the same shape but another colour highlights differences between objects belonging to one group. Signature sizes are based on the scale and character of the map. Geometric 
signatures are simple, easy to create and recognize signs, usually in the shape of regular geometric figures. Assigned meaning can be arbitrary, depending on the cartographer's idea. These symbols do not accurately represent real objects, therefore appropriate legend is necessary $[1,10]$.

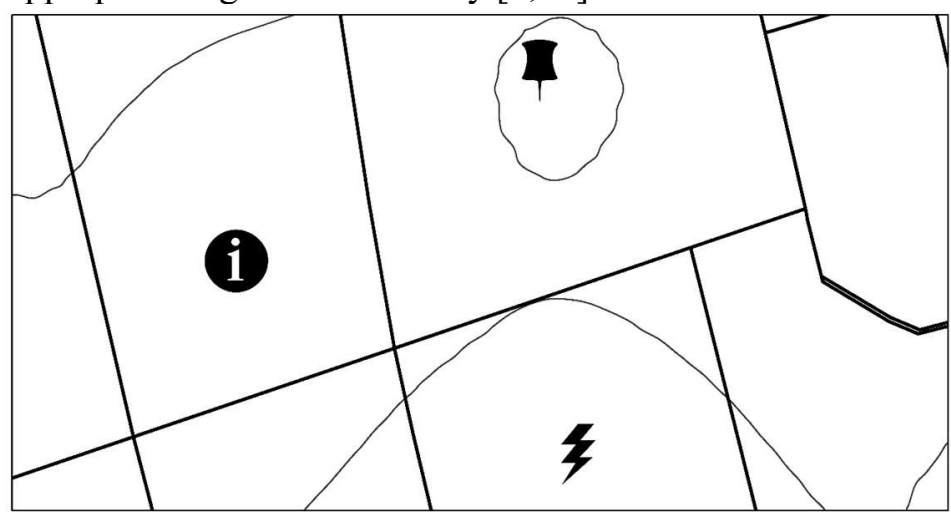

Fig. 2. More complex symbolic signatures Source: own elaboration

Symbolic signatures (Fig. 2) are designed to associate with the described object. Commonly known symbols are also used (such as road signs), as well as generally accepted information system signatures. Symbolic signatures are, in a sense, an extension of geometric signatures - their purpose is to facilitate the perception of the map [1].

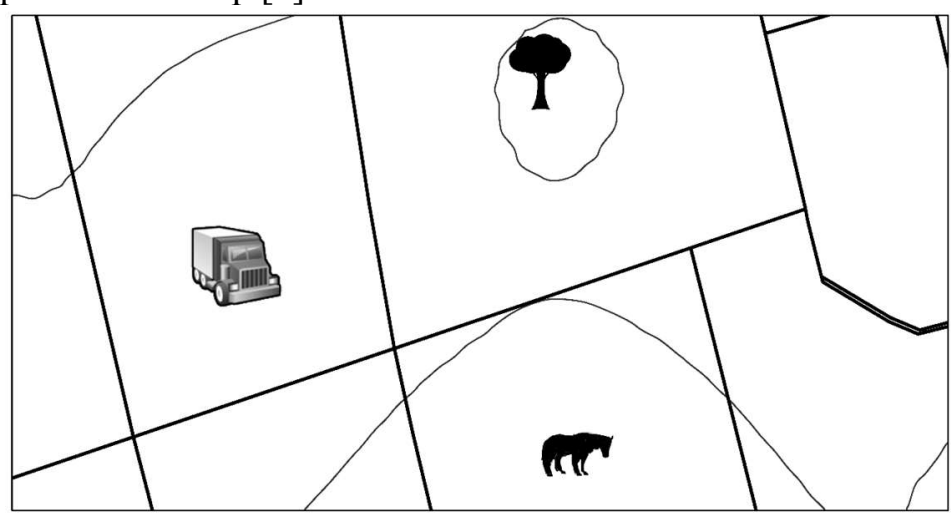

Fig. 3. Accurate representation with picture signatures Source: own elaboration

Picture signatures (Fig. 3) are the most accurate representation of the given content. Their shape directly defines the described object - they represent the entire object or part of it, as well as its single elements. This is a simple way to 
visualize data, mostly used for non-professional work, where the goal is to present a small amount of information [1].

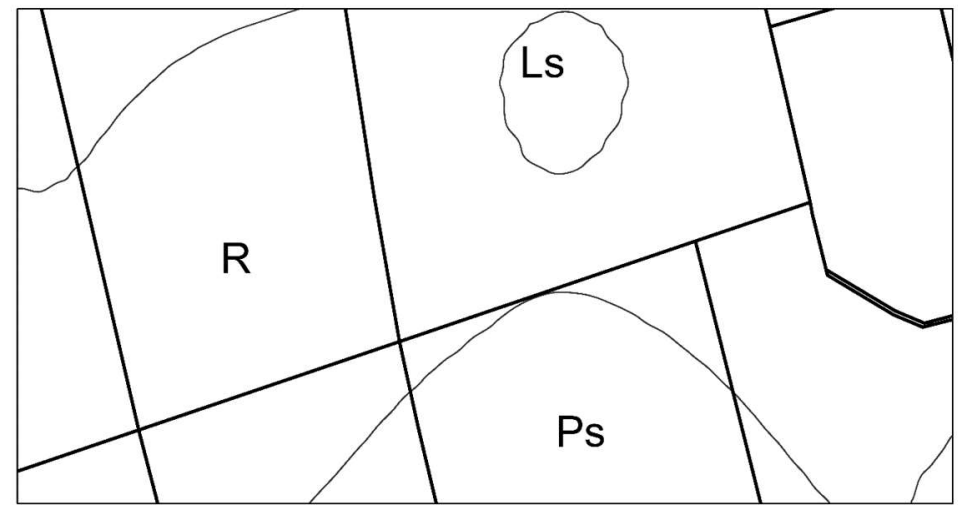

Fig. 4. Professional letter signatures

Source: own elaboration

Letter signatures (Fig. 4) represent the occurrence of objects by letters. For easier identification, signature usually consists of the first or the first two letters of described object's name. Due to the nature of this signature, receiver must be aware of the basic information about the nature of the presented issue, in order to fully and efficiently read the map [5].

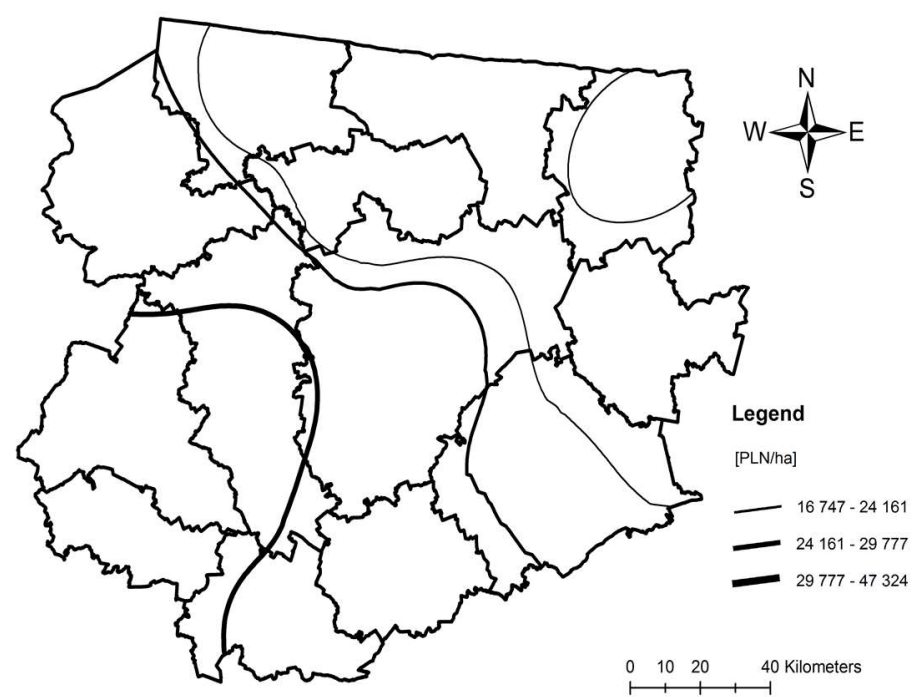

Fig. 5. Average transaction prices of the undeveloped land in Warmińsko-Mazurskie voivodeship - simple linear range, thicker lines means higher prices. Source: Own calculations based on data from APA RO Olsztyn 
Linear signatures are used to represent real linear objects. The basic information to distinguish certain types of objects are: pattern, value and colour. The linear symbol reflects all terrain points belonging to the linear object [10].

\subsection{Range method}

Method shows the spread of a given phenomenon, not considering its intensity. Coverage lines are drawn for this purpose, which by using different line types can be used for marking one range or many. Range lines show that a given issue occurs inside the covered area. However, this method can only give approximate location of the phenomenon, there is no certainty of its occurrence on whole covered area. Range lines are often used to represent the distribution of animals and plants on zoogeographic and phytogeographic maps. If range limits are not specified, occurrence of a given phenomenon can be specified by description [3]. With the linear range method (Fig. 5), the only means of transmission is the line. If there are multiple areas to be extracted on the map, different colours, patterns, or contour patterns are used. If the map shows an area smaller than the range, open coverage is used. Closed coverage is used if the whole range of occurrence of a given phenomenon is determined on the map [10].

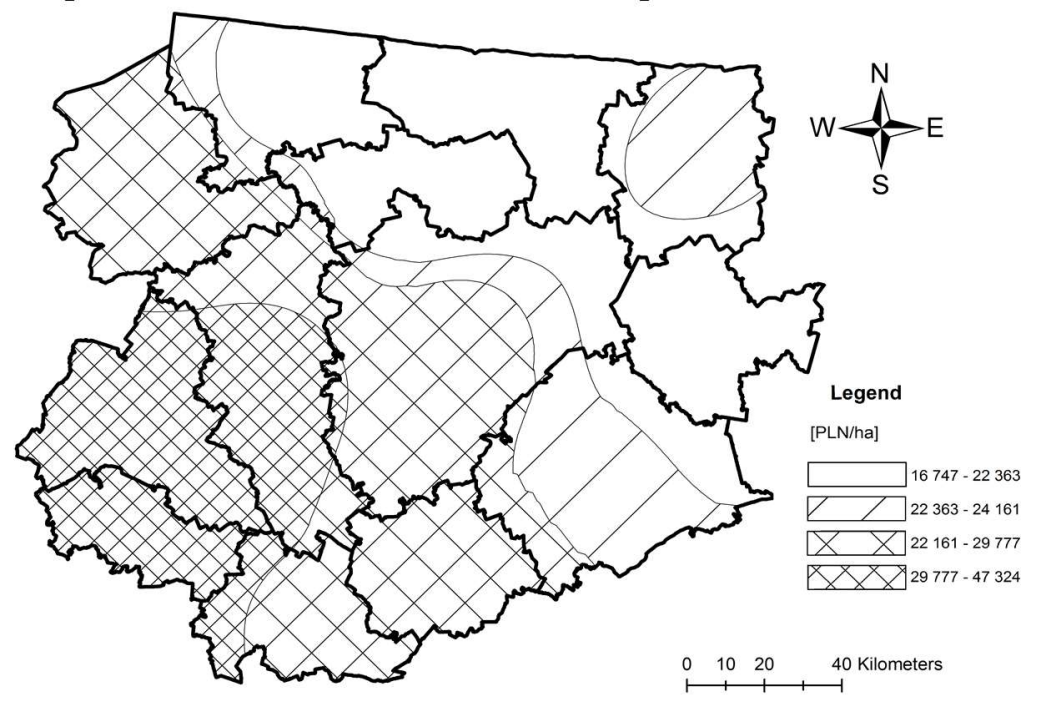

Fig. 6. Average transaction prices of the undeveloped land in Warmińsko-Mazurskie voivodeship - simple signature range, different signature means different prices. Source: Own calculations based on data from APA RO Olsztyn

Signature range (Fig. 6) is an extended version of the linear range. It consists of introducing a signature into the centre of a closed coverage, to include information about the object's content. This type of method is used in more elaborate studies [10]. 


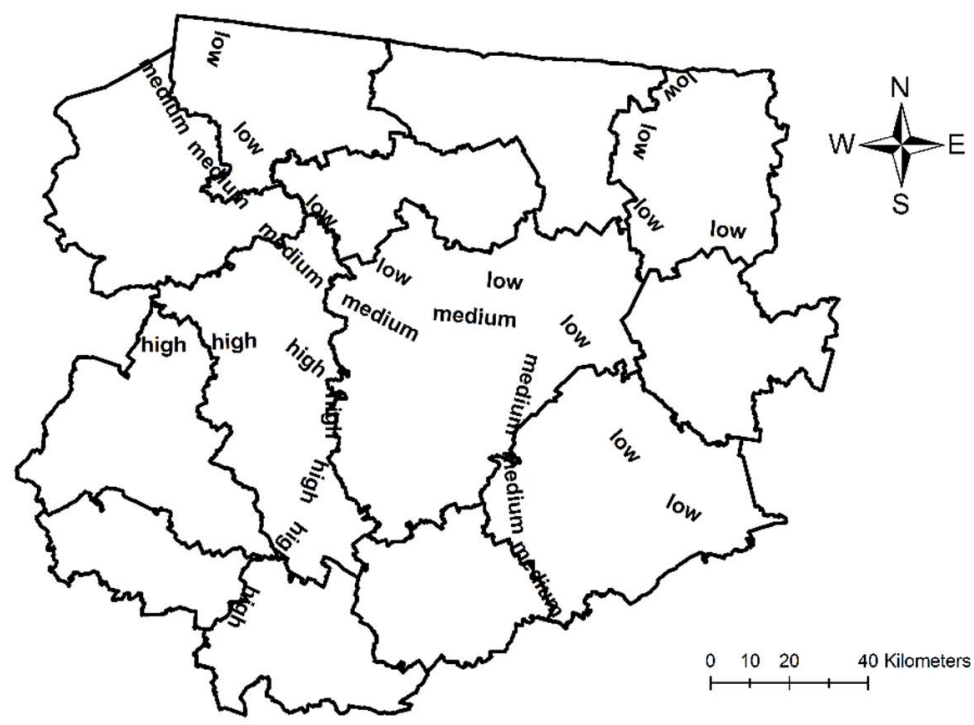

Fig. 7. Average transaction prices of the undeveloped land in Warmińsko-Mazurskie voivodeship - simple descriptive range.

Source: Own calculations based on data from APA RO Olsztyn

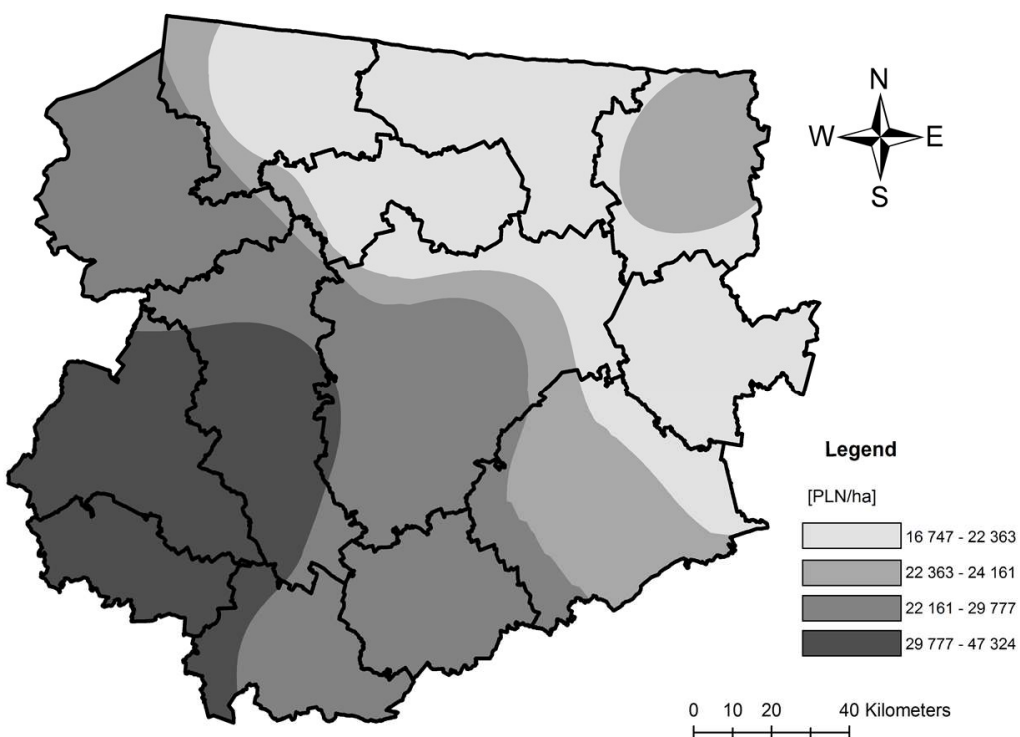

Fig. 8. Average transaction prices of the undeveloped land in Warmińsko-Mazurskie voivodeship - simple stain range, darker stains means higher prices.

Source: Own calculations based on data from APA RO Olsztyn 
If the nature of the phenomenon exceeds the level of border uncertainty (as described in stain range method), reaching the level of approximation, the descriptive range method is used (Fig. 7). This is a very inaccurate method, which only informs about occurrence of the phenomenon, without exact location information [10].

Within a stain range method, the closed coverage is filled with colour or pattern, excluding the contour - the area is shown with an inaccurate stain (Fig. 8). This can be used both in case of uncertainty of border data, as well as from uncertainty of the nature of the phenomenon [10].

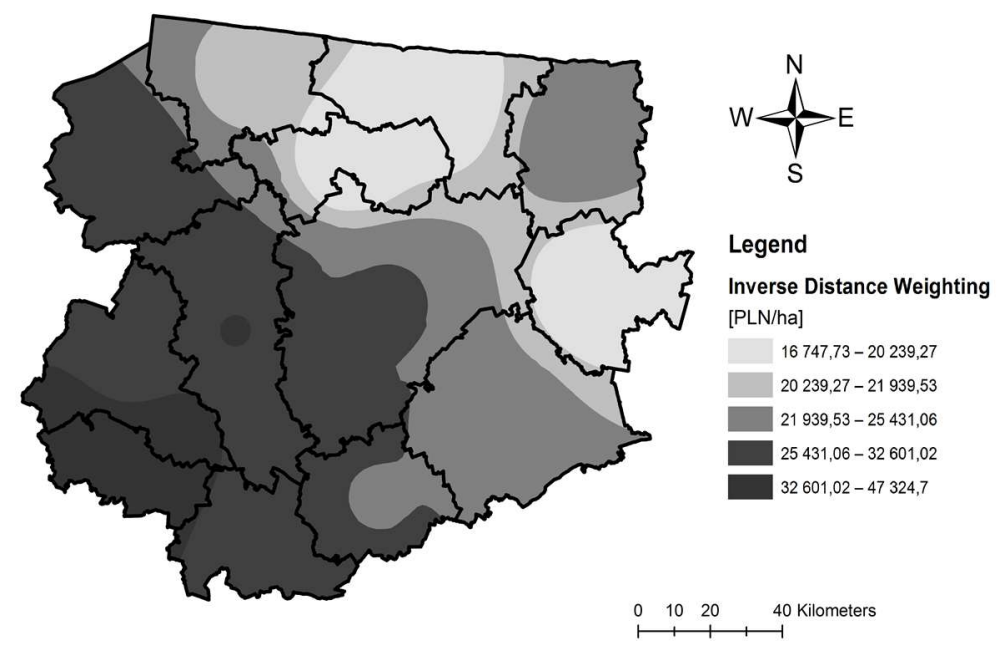

Fig. 9. Average transaction prices of the undeveloped land in Warmińsko-Mazurskie voivodeship - Inverse Distance Weight method, darker stains means higher prices. Source: Own calculations based on data from APA RO Olsztyn

\subsection{Geostatistical methods}

Various geostatistical methods can be used to visualise spatial and non-spatial data. Values of known points located nearby can be used to define values in an unknown point - this is the main principle of spatial interpolation methods [7]. There are two types of interpolation methods - deterministic and geostatistical. Deterministic interpolation techniques allows to create a model as a uniquely defined mathematical surface, so geographic objects located closer together are more similar to those located further away. With Inverse Distance Weighting (the simplest deterministic method, Fig. 9), the value in a given location is determined by the proximity of points with known values, which are weighted by a factor proportional to the inverse of their distance. Geostatistical 
methods are based on statistical models and use a statistical relationship between points with known values. Estimation of values in places where measurement data is missing can be done using the estimation method called Kriging (Fig. 10) $[2,13]$.

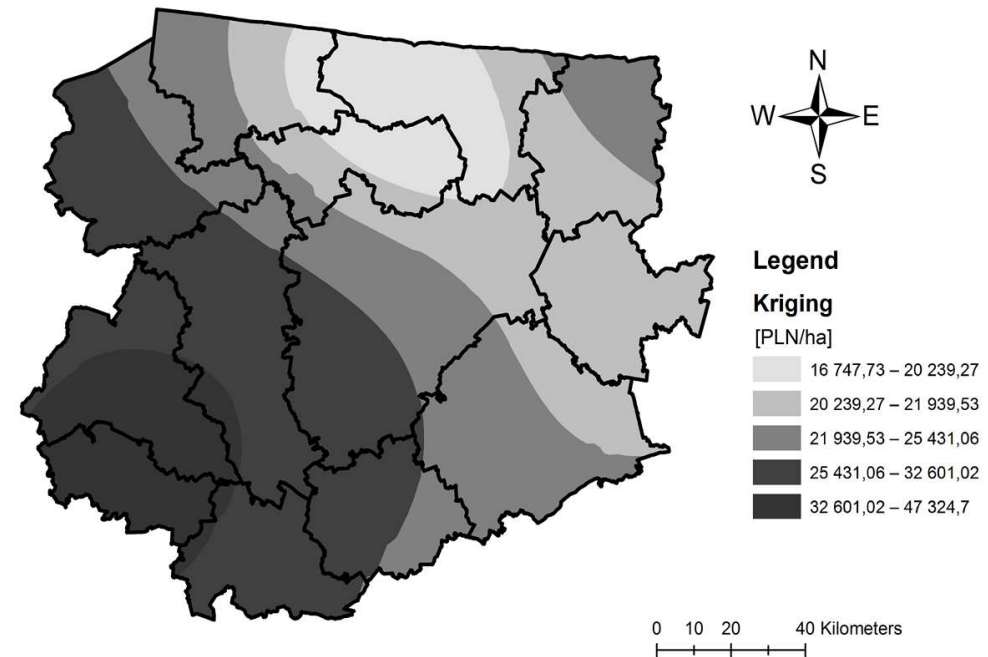

Fig. 10. Average transaction prices of the undeveloped land in Warmińsko-Mazurskie voivodeship - Kriging method, darker stains means higher prices. Source: Own calculations based on data from APA RO Olsztyn

\subsection{Surface method}

This method is also called chorochromatic method or method of qualitative background. It is an extended range method, consists of dividing the area into fields (mutually exclusive) different in terms of quality, with no overlapping areas. Map surface is divided into regions, that may represent regionalization. Regions are based on previous indicators, predetermined criteria [3]. The surface method is characterized by the qualitative characteristics of issue. Quantitative features are rarely used, and consists of laying out different surfaces by marking with colour scale or hachure. Therefore the least intense colour informs of the weak intensification and accordingly the most intense informs of the higher intensification. Occurrence of several phenomena on the same surface is attributed to a combination of the methods above. Surface method (Fig. 11) is often used in conjunction with signature methods [5]. 


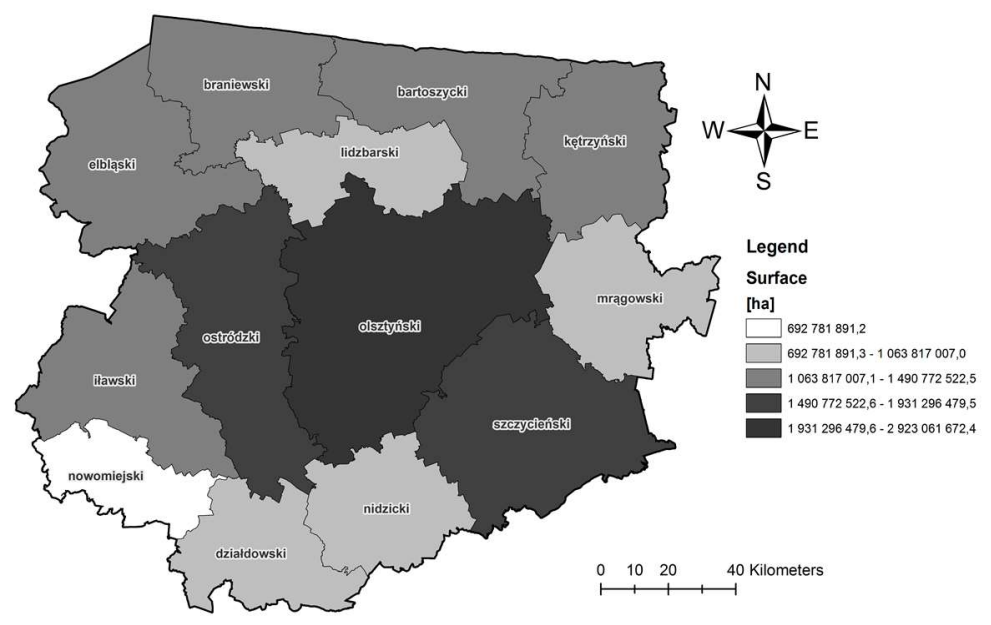

Fig. 11. Additional - area of districts in Warmińsko-Mazurskie voivodeship - simple surface method, darker colour means bigger surface.

Source: Own calculations based on data from APA RO Olsztyn

\section{QUANTITATIVE METHODS}

In quantitative methods relation between spatial variability and intensity of variation is shown. These methods allows to present the value of a given feature on the map - both numerical and ordinal values [10]. The basic of quantitative methods are: diagram map, choropleth map, dot map and contour lines. Quantitative methods are mostly used in statistical and geostatistical studies, because of ability to present specific statistics on the map. However, qualitative methods are also used to provide supplementary information [9].

\subsection{Diagram map (cartodiagram)}

The diagram map method consists of placing a graph within the territorial boundaries of the place of occurrence of a given phenomenon. This graph shows the size of a given issue in absolute numbers, so it gives its total characteristics within the boundaries of separate administrative units. However, the graph does not completely reflect the differences that occur within a territorial unit [4]. Linear diagrams are ideal for presentations of issues and objects where the predominant element is length, it displays quantitative values over the continuous interval or time span. It is used to show trends, patterns and relationships; to observe how issue develops over time. Pie charts are often used to represent the general value of a phenomenon (expressed by the surface of a circle) and the percentage of its components, it gives the reader a quick idea of the proportional 
distribution of the data. Surface diagrams usually use geometric figures to present proportional size of the phenomenon. The most common in this group are bar charts - it shows discrete, numerical comparisons across categories. Bar charts do not display continuous developments over an interval of time, only categorical data. The main functions are: comparison and pattern finding. Solid threedimensional diagrams are often used in popular publications, rarely in scientific studies. The volume of the presented solid is proportional to the size of the presented phenomenon. For more precise representation of quantitative relations, figures of equal shape and different sizes are often used [10,12].

The main disadvantage of the cartodiagram method is the imprecise representation of the location of the issue. Charts also cover certain parts of the map, giving the impression that the phenomenon is happening along the lines of territorial unit (which is false). However, the diagram map method (Fig. 12) is widespread because of the simplicity of the construction and the ease of reception $[5,11]$.

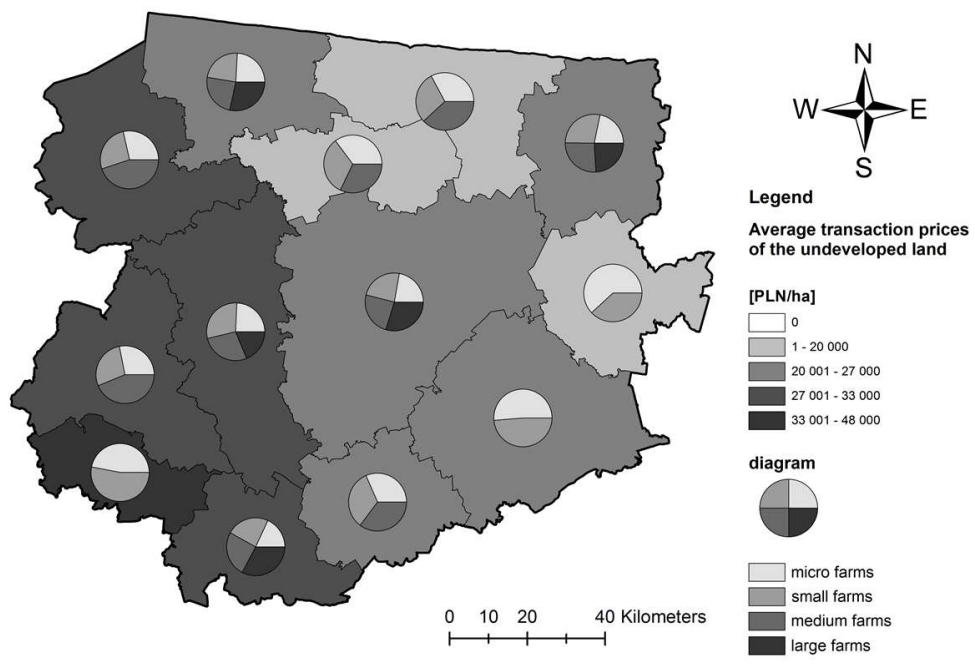

Fig. 12. Average transaction prices of the undeveloped land in Warmińsko-Mazurskie voivodeship - diagram map with pie charts of micro, small, medium and large farms (darker colour means higher average prices and bigger farms). Source: Own calculations based on data from APA RO Olsztyn

\subsection{Choropleth map}

This method presents the phenomenon by its value within the boundaries of a given territorial unit. To illustrate the intensity, each administrative unit is described with the precise colour, shade or hachure (and should cover the entire 
surface of the terrain on the map) - change of intensity of a given phenomenon corresponds to a change in intensity of a given colour, shade or hachure [4].

The element that illustrates the intensity of a given phenomenon is the graphic scale chosen by the creator. In order to emphasize the intensity change of a given phenomenon, different shades (from light to dark ones) are used more often, rather than several colours. A common error when creating choropleth map is to present raw data values (such as population) rather than using normalized values (e.g. calculating population per square kilometre) to produce a density map [9]. Despite the popularity, this method gives the false impression that the intensity does not change within the unit of the area. However, within each territorial unit, the feature is characterized by a certain degree of differentiation [9].

Another disadvantage of the choropleth map is the freedom of choice of scale, which can change the appearance of a given phenomenon. This proves the sensitivity of this method to the misstatements caused by the error of the creator or his intentional action. Another negative aspect of this method is the fact that there is an impression of a radical change in the intensity of a given phenomenon at the border of two territorial units, which in reality does not exist in the vast majority of cases [4]. At each stage of the work, user may encounter many elements that force to make a decision - it affects the final result. But despite the negative aspects, choropleth map (Fig. 13), preceded by appropriate data analysis, is a very appropriate, safe and most versatile way of presenting basic spatial data [8].

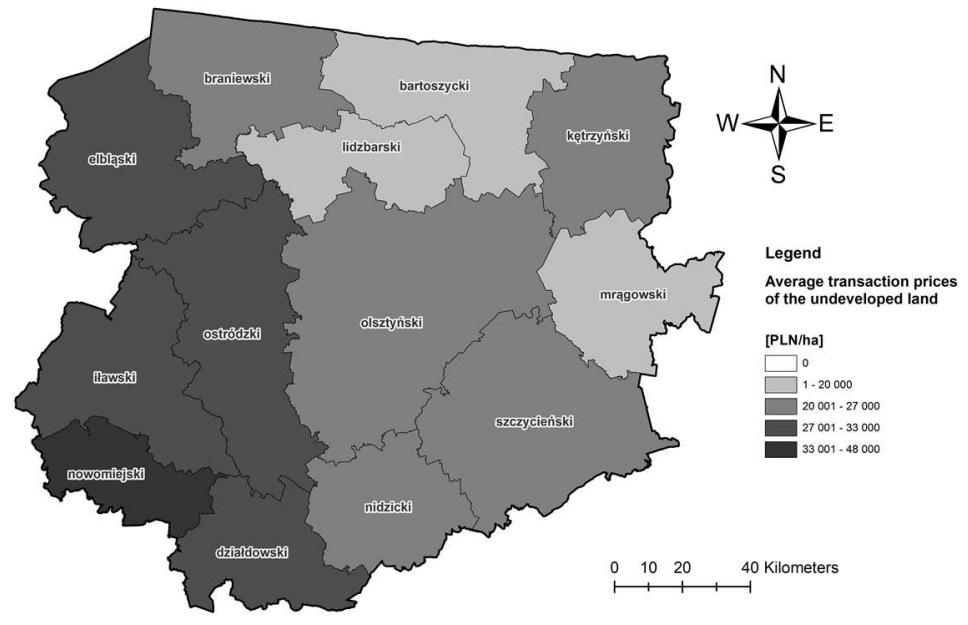

Fig. 13. Average transaction prices of the undeveloped land in Warmińsko-Mazurskie voivodeship - choropleth map, darker colour means higher prices. Source: Own calculations based on data from APA RO Olsztyn 


\subsection{Dot map}

Dot map method (Fig. 14) illustrates the intensity of a given phenomenon relative to the surface. It consists of assuming that a given number of units of a given issue corresponds to a point of a certain size. The point's weight is the number of units of a given phenomenon corresponding to one point, this choice depends on the scale of the map. Using the dot map method, a fairly faithful image of the distribution of the phenomenon is given, simplicity and viewability allows for its wide application. Dot maps are a way of detecting spatial patterns or the distribution of data over a geographical region [10].

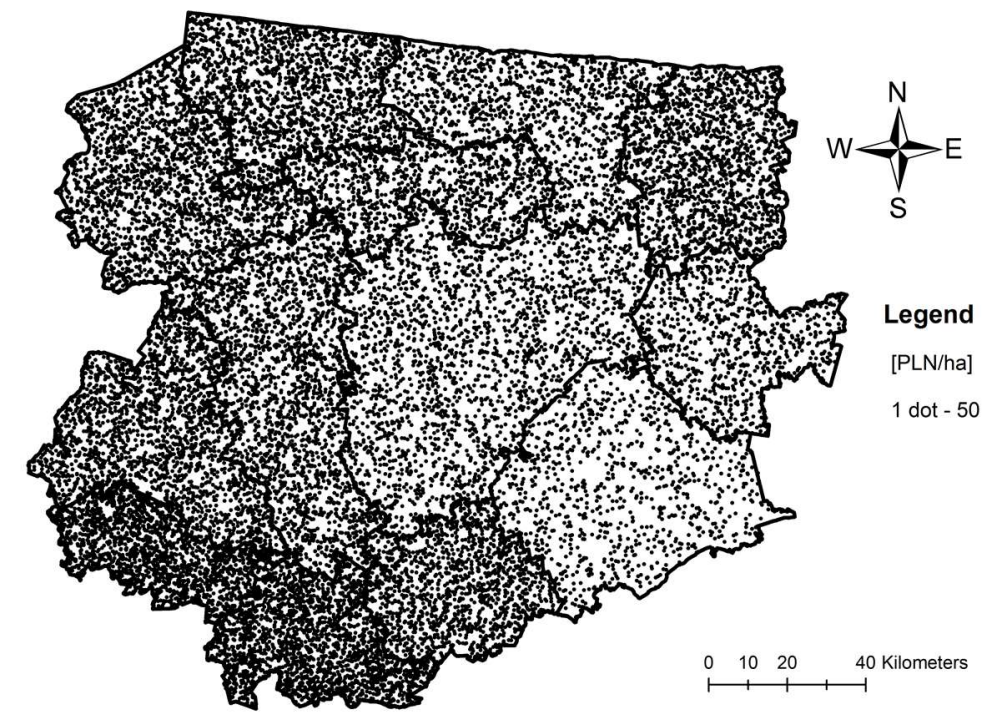

Fig. 14. Average transaction prices of the undeveloped land in Warmińsko-Mazurskie voivodeship - dot map, higher dot density means higher prices. Source: Own calculations based on data from APA RO Olsztyn

\subsection{Contour lines (isolines)}

The contour lines method (Fig. 15) is based on the assumption that the phenomenon occurs evenly within the area - features are represented by lines connecting points of the same value. These lines are called isolines. These lines are determined by the averaging of the values between the various measuring points. The basic disadvantage of this method is the fact, that the vast majority of isolines are not based on data derived from measurements, but on a number of averaged points received by interpolation. Thus the isolines simplify the picture of the shown phenomenon. The main advantages of this method is the replacement of the somewhat artificial boundaries of territorial units occurring in 
the choropleth maps with well spread isolines. To distinguish individual lines, appropriate description is necessary (or at least suitable colour scale) [10].

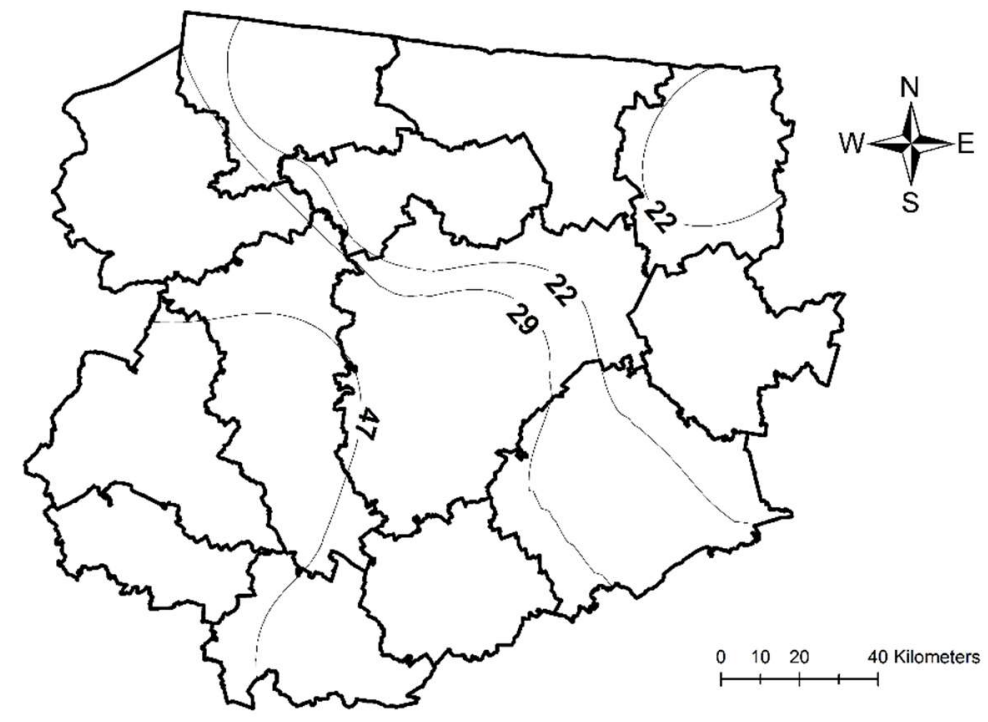

Fig. 15. Average transaction prices of the undeveloped land in Warmińsko-Mazurskie voivodeship - contour lines, lines connect places with the same price [thousand PLN/ha].

Source: Own calculations based on data from APA RO Olsztyn

\section{CONSLUSIONS}

Information on average transaction prices of the undeveloped land in WarmińskoMazurskie voivodeship, from The Agricultural Property Agency, Regional Office in Olsztyn, was used to present basic cartographic methods used to visualize spatial data. First, 10 qualitative methods was described and simple examples was shown, presenting differences in methods (using sample data). Four quantitative methods was later described (using data from The Agricultural Property Agency, Regional Office in Olsztyn), showing differences in various methods. The objective was not to determine the best method for presenting spatial data - it is impossible due to diversity in geospatial information. Many variations of available cartographic methods, and its differentiation shows, that the process of accurate choice of spatial data presentation method by identifying the data structure and visualization purpose needs to be vital part in the analysis process. 


\section{ADDITIONAL INFORMATION}

The research are supported by grant no. UMO-04/SFKiW/2017 from the Agricultural Property Agency RO Olsztyn.

\section{REFERENCES}

1. Anson R.W., Ormeling F.J., Basic Cartography: For Students and Technicians; Exercise Manual, Amsterdam, Elsevier, 2013.

2. Cichociński P.: Porównanie metod interpolacji przestrzennej $w$ odniesieniu do wartości nieruchomości, Studia i materiały Towarzystwa Naukowego Nieruchomości, 19, 3 (2011) 122-133.

3. Dykes J., MacEachren A.M., Kraak M.J., Exploring Geovisualization, Oxford, Pergamon Press, 2005.

4. Graficzna prezentacja danych statystycznych. Wykresy, mapy, GIS, Główny Urząd Statystyczny, Warszawa 2014.

5. Mapy statystyczne. Opracowanie i prezentacja danych, Główny Urząd Statystyczny, Warszawa 2016.

6. MacEachren A.M., Taylor D.R.F., Visualization in Modern Cartography Volume 2, Oxford, Pergamon Press, 1994.

7. Ogryzek, M., Kurowska, K.: Opracowanie map średnich cen transakcyjnych gruntów rolnych niezabudowanych zbywanych z zasobu ANR OT Olsztyn $z$ wykorzystaniem interpolacji metoda IDW, Metody ilościowe w ekonomii, 2, 45 (2016) 355-365.

8. Olenderek T.: Niezawodna metoda wizualizacji ilościowych cech przestrzeni leśnej, Roczniki Geomatyki, 8, 7 (2010) 49-56.

9. Pasławski, J.: Uwagi o klasyfikacji ilościowych form prezentacji kartograficznej, Polski Przegląd Kartograficzny, 37, 2 (2005) 95-100.

10. Pasławski, J.: Wprowadzenie do kartografii i topografii, Nowa Era 2006

11. Rhind D.W., Taylor D.R.F., Cartography Past, Present and Future, Oxford, Pergamon Press, 1989.

12. Taylor D.R.F, Reflexive Cartography Volume 6, Oxford, Pergamon Press, 2013.

13. Taylor D.R.F, Geographic Information Systems Volume 1, Oxford, Pergamon Press, 2016. 


\section{KARTOGRAFICZNE METODY PREZENTACJI ŚREDNIEJ CENY TRANSAKCYJNEJ GRUNTÓW ROLNYCH NIEZABUDOWANYCH}

\section{Streszczenie}

Artykuł przedstawia opis podstawowych metod kartograficznych wykorzystywanych do wizualizacji danych przestrzennych. Podstawą do stworzenia opracowań mapowych były dane o średnich cenach transakcyjnych nieruchomości gruntowych niezabudowanych w województwie warmińsko-mazurskim, pochodzące z Agencji Nieruchomości Rolnych, Oddział Terenowy w Olsztynie. Ujednolicone dane pozwalają na dokładne przedstawienie i uwidocznienie różnic w wybranych metodach kartograficznych. Celem artykułu jest opisanie procesu wyboru najlepszej metody przedstawiania danych przestrzennych, poprzez identyfikację struktury danych oraz celu wizualizacji; a także scharakteryzowanie poszczególnych rodzajów ich prezentacji w celu ich potencjalnego wykorzystania do prac związanych z czynnościami wykonywanymi przez osoby zajmujące się zawodowo rynkiem nieruchomości oraz przez osoby prywatne.

Słowa kluczowe: metody kartograficzne, dane przestrzenne, ceny transakcyjne gruntów rolnych niezabudowanych

Editor received the manuscript: 9.11.2017 